\title{
Perbandingan Boolean Model Dan Vector Space Model Dalam Pencarian Dokumen Teks
}

\author{
Susanti ${ }^{1}$, Muhammad Azmi ${ }^{2},{\text { Edwar } \mathrm{Ali}^{3}, \text { Rahmaddeni }^{4} \text {, Yansyah Saputra Wijaya }}^{5}$ \\ $\mathbf{1 , 2 , 3 , 4 , 5}$,Program Studi Teknik Informatika STMIK Amik Riau \\ Jl Purwodadi Indah Km.10 Panam, Pekanbaru, Riau, +62 81317179817 \\ e-mail: ${ }^{1}$ susanti@sar.ac.id, ${ }^{2}$ m_azmi@sar.ac.id, ${ }^{3}$ edwarali@sar.ac.id ${ }_{3}^{4}$ rahmaddeni@sar.ac.id, \\ 5yansyahwijaya@sar.ac.id
}

\begin{abstract}
Abstrak
Perkembangan teknologi informasi di era globalisasi saat ini, membuat semua aspek kehidupan kita berubah dan tidak dapat dihindarkan dari pengaruh kemajuan zaman. Untuk mendapatkan data dan informasi yang kita inginkan bukanlah perkara mudah, mengingat sedemikian banyaknya informasi yang tersedia untuk berbagai keperluan dengan berbagai gaya penyajian. Pencarian data di komputer, baik itu secara online ataupun offline berkembang banyak metode yang semakin menyempurnakan hasil pencarian. Hal ini juga meningkatkan kepuasan pengguna dalam mencari informasi. Metode yang umum digunakan dalam melakukan pencarian adalah Boolean Model. Metode lainnya adalah Vector Space Model (VSM). VSM yaitu model yang digunakan untuk mengukur kueri antara suatu dokumen dengan suatu kata kunci. Oleh karena itu, penulis bertujuan untuk membandingkan kedua metode tersebut dari kecepatan (waktu) pencarian dan jumlah temuan. Kecepatan tersebut dihitung berdasarkan lama waktu pencarian untuk kedua metode tersebut. Hasil yang didapati adalah perbandingan waktu pencarian antara boolean model dan vector space model didapati bahwa boolean model lebih cepat dengan selisih 30 sampai 50 detik. Perbandingan untuk hasil temuan didapati bahwa vector space model mempunyai hasil temuan yang sama dengan boolean model yang menggunakan operator or, sedangkan dengan operator and dan gabungan and serta or didapati bahwa jumlah hasil temuan tidak sama dengan vector space model.
\end{abstract}

Kata kunci: Perbandingan, Boolean Model, Vector Space Model, Pencarian, Dokumen Teks

\begin{abstract}
The development of information technology in the current era of globalization, makes all aspects of our lives change and cannot be avoided from the influence of the times. To get the data and information that we want is not an easy matter, considering that so much information is available for various purposes with various styles of presentation. Searching data on a computer, be it online or offline, there are many methods that improve the search results. It also increases user satisfaction in finding information. The most commonly method of searching is the Boolean Model. Another method is the Vector Space Model (VSM). VSM is a model used to measure queries between a document and a keyword. Therefore, the authors aim to compare the two methods from the speed (time) of the search and the number of findings. The speed is calculated based on the search time for both methods. The result is that the comparison between boolean model and vector space model shows that the boolean model is faster by a difference of 30 - 50 seconds. The comparison for the foundings document text shows that vector space model has the same findings as the boolean model using the or operator, whereas with the and operator and the combination of operator and or it is found that the number of findings is not the same as vector space model.
\end{abstract}

Keywords: Comparison, Boolean Model, Vector Space Model, Search, Text Documents 


\section{Pendahuluan}

Perkembangan teknologi komputer dianggap sebagai suatu penemuan yang mengubah dunia dari era manual menjadi digital, kemudian komputer juga mulai menggantikan kemampuan mesin ketik, kalkulator dan sampai kemampuan dalam memberikan informasi melalui internet. Internet sendiri semakin menyatu dengan kehidupan sosial manusia. Internet memiliki kemampuan untuk memberikan berbagai bentuk layanan. Salah satunya adalah penyediaan data dan informasi. Namun untuk mendapatkan data dan informasi yang kita inginkan bukanlah perkara mudah, mengingat sedemikian banyaknya informasi yang tersedia untuk berbagai keperluan dengan berbagai gaya penyajian. Berbagai mesin pencari telah tersedia dan masing-masingnya memiliki strategi, fitur dan kemampuan. Bentuk sederhana dari proses pencarian itu dapat dimulai dari pencarian data dalam sebuah dokumen dalam sebuah komputer.

Pencarian data di komputer, baik itu secara online ataupun offline telah berkembang banyak metode yang semakin menyempurnakan hasil pencarian. Hal ini juga meningkatkan kepuasan end user dalam mencari informasi [1]. Para pakar kecerdasan buatan semakin meningkatkan cara kerja pencarian dokumen dengan algoritma dan metode yang mendekati alamiah pikiran manusia [2] [3]. Metode yang umum digunakan dalam melakukan pencarian adalah Boolean Model. Metode ini memiliki sistem pencarian langsung menggunakan dasar hukum Boole. Aljabar boole merumuskan beberapa operator matematika antara AND, OR, NOT, NOT AND dan NOT OR [4] [5]. Jika mesin pencari menemukan kesesuaian dokumen sesuai dengan kata kunci maka langsung ditampilkan sebagai hasil temuan [1].

Metode lainnya adalah Vector Space Model (VSM). VSM yaitu model yang digunakan untuk mengukur kueri antara suatu dokumen dengan suatu kata kunci. Konsep dasar VSM adalah menghitung jarak vector antara dokumen dengan kata kunci yang dimasukkan kemudian mengurutkan berdasarkan tingkat kedekatannya [6] [7] [8] [9]. Semakin kecil jarak vektor antar dokumen maka semakin mirip keduanya [10] [11] [12]. Teknik ini juga ternyata menjadi alternatif dalam mesin pencari untuk menyelesaikan tugasnya. Boolean Model dan VSM memiliki persamaan cara dalam melakukan pencarian yaitu dengan menemukan setiap kata yang sama dengan kata kunci yang dimasukkan oleh user dibandingkan dengan dokumen yang mencari obyek pencarian. Jika ditemukan persamaan kata maka akan disebut sebagai dokumen yang ditemukan [13] [12].

Penelitian yang terkait dengan topik penelitian yang dibahas adalah didapati bahwa Vector Space Model memberikan peningkatan kinerja pengklasifikasian dari binomial dan polinomial [14]. Penelitian membandingkan pencarian Boolean dan Vector Space Model didapati bahwa Boolean dan Vector Space Model mempunyai hasil yang sama dalam pencapaian dokumen [15]. Oleh karena itu penelitian ini bertujuan untuk membandingkan lagi kedua metode tersebut dari kecepatan (waktu) pencarian dan jumlah temuan. Kecepatan tersebut dihitung berdasarkan lama waktu pencarian untuk kedua metode tersebut yaitu Boolean dan Vector Space Model.

\section{Metode Penelitian}

\subsection{Pengumpulan data}

Aspek ini mencakup pendalaman pengetahuan yang berkaitan dengan metode-metode pencarian yang ada dan lebih fokus yang pada paling relevan terhadap topik yang dikaji.

\subsection{Analisa}

Pada tahap ini dilakukan analisa dalam proses pencarian dokumen dengan menggunakan 2 buah metode yang akan menjadi bahan perbandingan yaitu Boolean model dan Vector Space Model (VSM). Hasil pencarian tadi akan menjadi sumber data indexing yang disimpan ke dalam basis data dan kemudian disalurkan ke sistem temu-kembali agar user dapat membaca hasil pencarian yang dilakukan. Perencanaan sistem ini dilakukan dengan menggunakan Unifield Modelling Language (UML). Menurut Febri dan Amalia (2018) menyatakan bahwa dengan pemodelan UML dapat meningkatkan kinerja sistem informasi pengajuan dana anggaran, sehingga meningkatkan produktifitas perusahaan [16]. Penelitian ini juga menggunakan UML. 


\subsection{Perancangan Sistem}

Setelah melakukan analisa, perlu untuk segera merancang sistem Pencarian dokumen. Dalam pencarian dokumen diperlukan beberapa bagian sistem antara lain perancnagan output, input dan proses.

\subsection{Logika Proses Pencarian}

Setelah dilakukan input maka proses pencarian dilakukan. Proses pencarian ini menggunakan 2 metode pencarian yaitu Boolean Model dan VSM. Pada metode pencarian dengan VSM tidak diperlukan aturan penulisan kata kunci, sedangkan Boolean Model diberlakukan beberapa aturan penulisan kata kunci yaitu:

a. Untuk proses menggunakan operator "AND" dapat dilakukan dengan memberikan tanda "-".

b. Untuk proses menggunakan operator "OR" dapat dilakukan dengan memberikan tanda spasi atau “ ". Logika pencarian dengan Boolean Model dapat terlihat dalam Gambar 1.

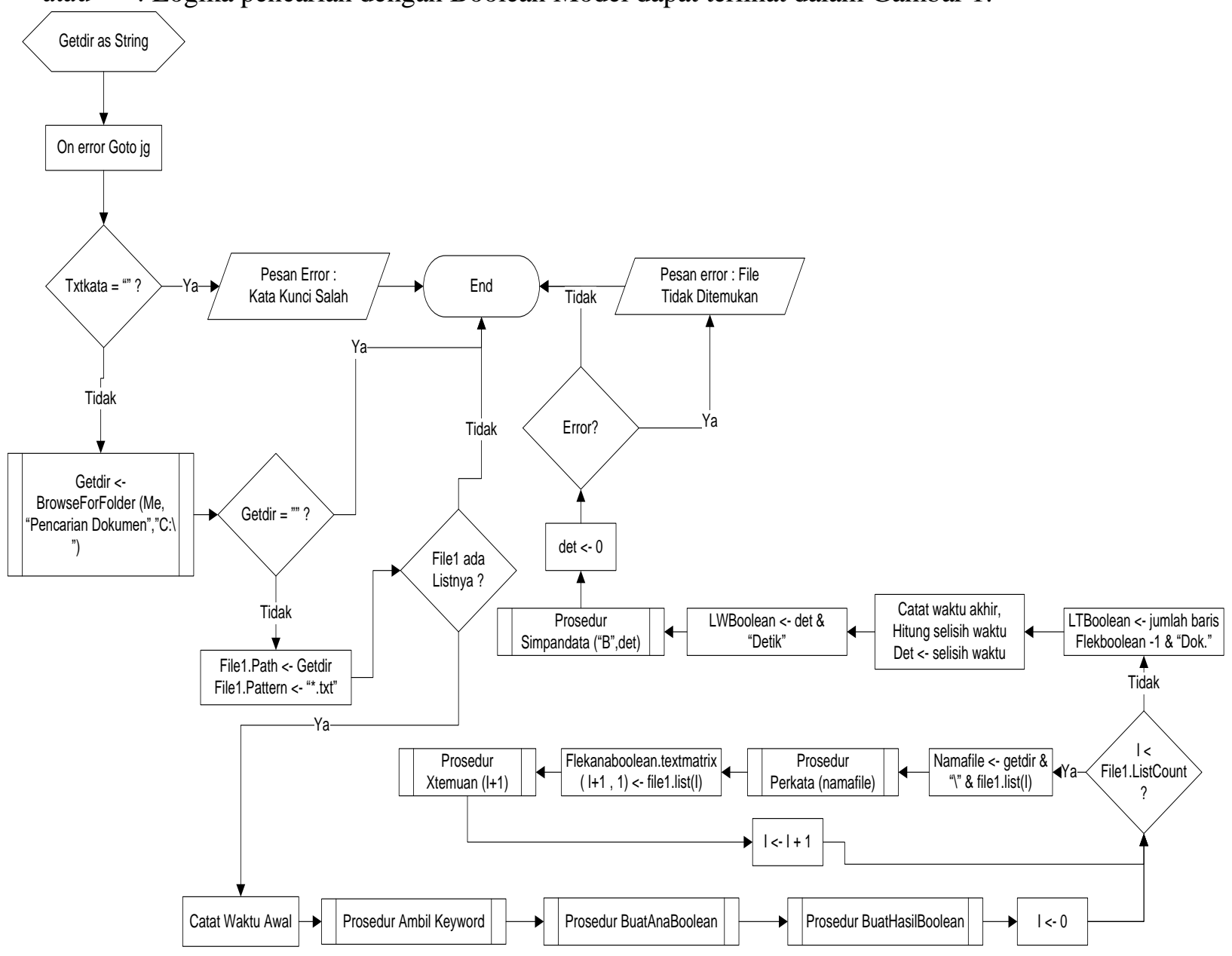

Gambar 1. Flowchart Pencarian dengan Boolean Model

Gambar 1, dapat dilihat logika yang terjadi pada pencarian menggunakan Boolean Model. Penghitungan waktu pencarian dimulai setelah folder yang dijadikan target dipastikan memiliki file bertipe txt, setelah itu diikuti serangkaian pengujian melalui berbagai prosedur seperti terlihat pada gambar diatas. Penghitungan waktu pencarian akan dihentikan setelah jumlah dokumen yang ditemukan telah dipastikan. Dengan demikian dapat dipastikan keakuratan pencarian sesuai dengan kebutuhan pencarian tersebut. Logika pencarian dengan VSM terlihat dalam Gambar 2. 


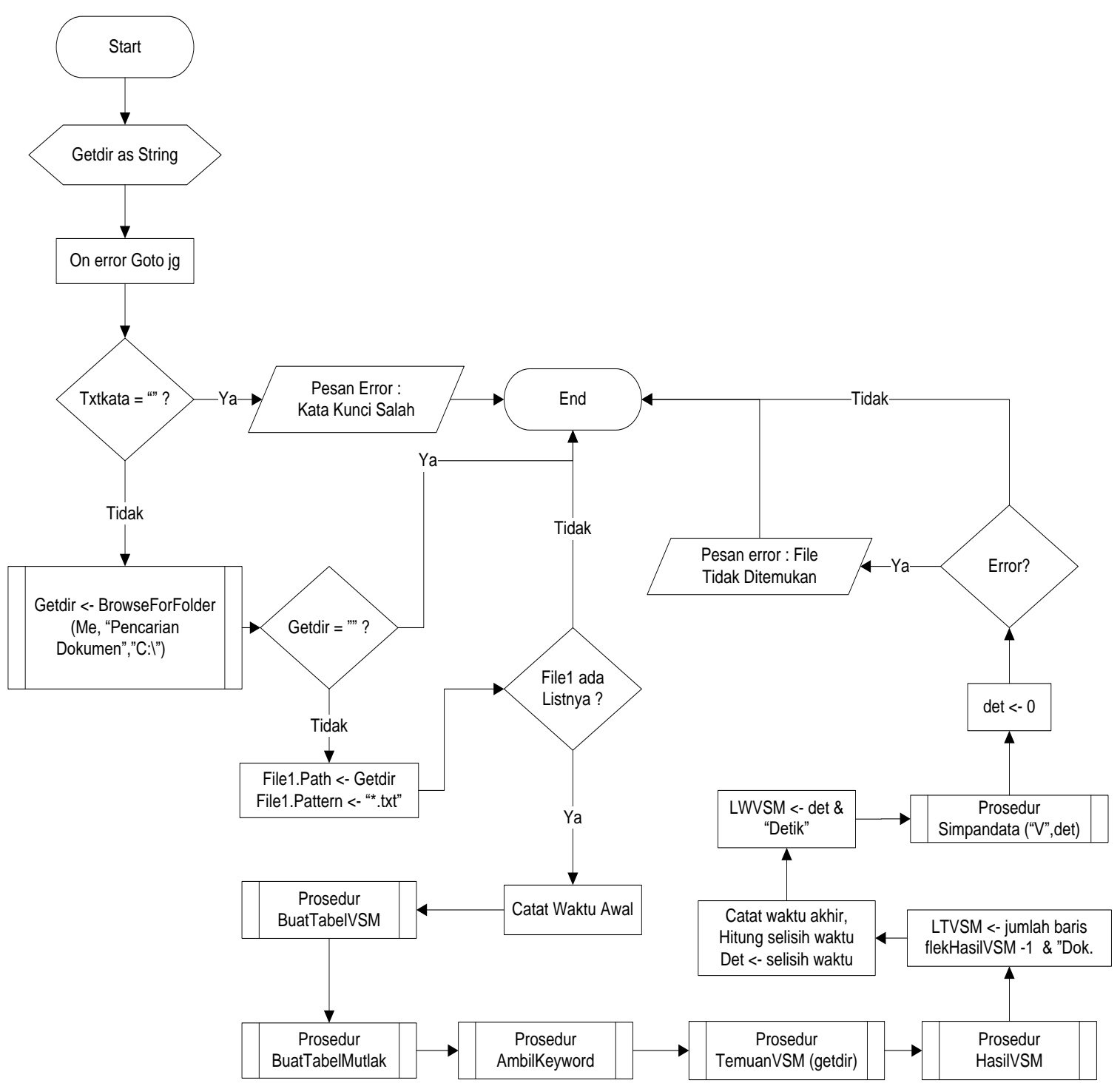

Gambar 2. Flowchart Pencarian dengan Vector Space Model

Gambar 2 menjelaskan bahwa, pada pencarian dengan VSM awal prosesnya sama dengan pencarian dengan Boolean Model yaitu memilih folder yang menjadi obyek pencarian. Setelah dipastikan jenis dokumen teks memang terdapat pada folder tersebut maka penghitungan waktu dimulai, kemudian dilanjutkan dengan melaksanakan prosedur Buat Tabel VSM, yaitu menyiapkan tabel untuk media pencatatan proses dasar dari VSM. Setelah itu diikuti dengan prosedur BuatTabelMutlak, yaitu Menyiapkan tabel untuk media pencatatan similarity Analysis dari VSM. Setelah tahap persiapan selesai, dilanjutkan dengan prosedur Ambil Keyword yang berguna menyediakan kata kunci dalam tabel sebagai acuan pencarian dokumen, dan diteruskan dengan prosedur Temuan VSM dan Hasil VSM sebagai rangkaian proses untuk menemukan dan menampilkan dokumen dengan Vector Space Model. Berdasarkan hasil dari HasilVSM tadi, dapat dilaporkan jumlah temuan dokumen, maka dapat dilanjutkan dengan mengakhiri penghitungan waktu pencarian dan menjadi total waktu pencarian. Kemudian dilakukan prosedur Simpan Data.

\section{Hasil dan Pembahasan}

Aplikasi perbandingan Boolean Model dengan VSM ini hanya terdiri dari satu form pengujian/pencarian dan satu form lainnya untuk pelaporan dan analisanya. Aplikasi dijalankan dengan cara masukkan kata kunci yang diinginkan, tetapi yang harus diingat bahwa untuk 
pencarian dengan Boolean Model fungsi "Or" ditandai dengan spasi antar kata, dan fungsi "And" ditandai dengan tanda "_." antar kata, sedangkan pada VSM tidak memiliki aturan seperti di Boolean model.

\subsection{Pengujian Sistem}

Pengujian sistem dilakukan dengan menggunakan sampel dengan 3 (tiga) dokumen teks yaitu:

a. Doc1.txt, dengan isi adalah "Shipment of gold damaged in a fire".

b. Doc2.txt, dengan isi adalah "Delivery of silver arrived in a silver truck"

c. Doc3.txt, dengan isi adalah "Shipment of gold arrived in a truck"

Kemudian akan digunakan kata kunci yang sama yaitu "gold silver truck", namun dengan mengindahkan kemungkinan aturan "And" dan "Or" pada pencarian dengan Boolean Model.

\subsubsection{Pengujian Boolean Model}

Pada pengujian Boolean Model dilakukan 4 kali pengujian dengan kombinasi fungsi "And" yang diwaliki dengan tanda "_" dan "Or" yang diwakili dengan tanda spasi, sehingga didapat kata kunci yang diterapkan adalah sebagai berikut :

a. Gold silver truck

b. Gold-silver-truck

c. Gold-silver truck

d. Gold silver-truck

\section{A. Pengujian dengan Operator $\mathrm{Or}$}

Ketika digunakan kata kunci pertama yaitu "gold silver truck", maka terlihat hasilnya dalam Gambar 3.

\begin{tabular}{|c|c|}
\hline HasilP & Pencarian Metode : Boolean Model \\
\hline NO & File Hasil Temuan \\
\hline & D: lazmilaplik asildok \vsmidoc1. Lkt \\
\hline & D:'azmilaplikasildokłvsmidoc2.tkt \\
\hline & 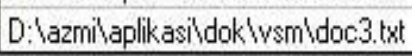 \\
\hline
\end{tabular}

Gambar 3. Hasil Pencarian Boolean Model dengan operator Or

Gambar 1, terlihat bahwa dari 3 (tiga) dokumen sampel seluruhnya menjadi temuan dan total waktu yang dibutuhkan untuk keseluruhan prosesnya adalah 30 milidetik.

\section{B. Pengujian dengan Operator And}

Ketika digunakan kata kunci kedua yaitu "gold-silver-truck", yaitu menggunakan operator and, maka terlihat hasil temuan dalam Gambar 4.

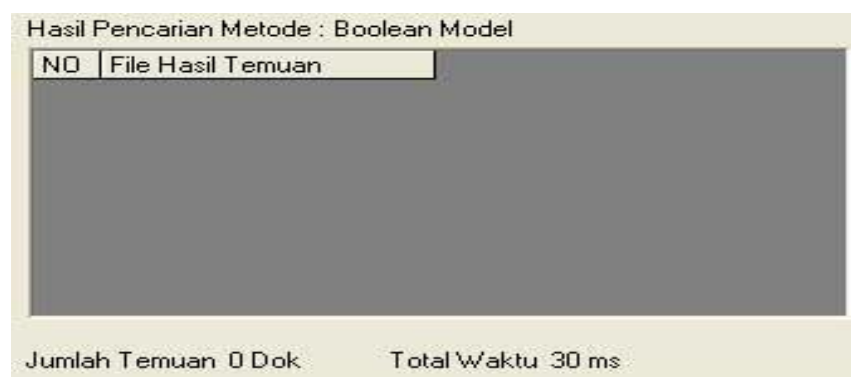

Gambar 4. Hasil Boolean Model dengan operator And

Gambar 4, terlihat bahwa tidak ada dokumen sampel menjadi temuan dan total waktu yang dibutuhkan untuk keseluruhan prosesnya adalah 30 milidetik.

\section{Pengujian dengan Gabungan Operator And dan $\mathrm{Or}$}

Ketika digunakan kata kunci ketiga yaitu "gold-silver truck", atau menggunakan operator And dan $O r$ terlihat hasilnya dalam Gambar 5. 


\begin{tabular}{|c|c|}
\hline \multicolumn{2}{|c|}{ Hasil Pencarian Metode : Boolean Model } \\
\hline NO & File Hasil Temuan \\
\hline & D: lazmilaplikasìdok vsmidoc2.txt \\
\hline & D: Sazmilaplikasildok \vsmidoc3.txt \\
\hline
\end{tabular}

Gambar 5. Hasil Pencarian Boolean Model dengan Operator And dan $\mathrm{Or}$

Gambar 5, terlihat bahwa 2 (dua) dokumen sampel menjadi temuan dan total waktu yang dibutuhkan untuk keseluruhan prosesnya adalah 30 milidetik.

\section{Pengujian dengan Gabungan Operator Or dan And}

Ketika digunakan kata kunci keempat yaitu "gold silver-truck", atau dengan menggunakan gabungan operator $O r$ dan And, maka terlihat hasil pencarian dalam Gambar 6.

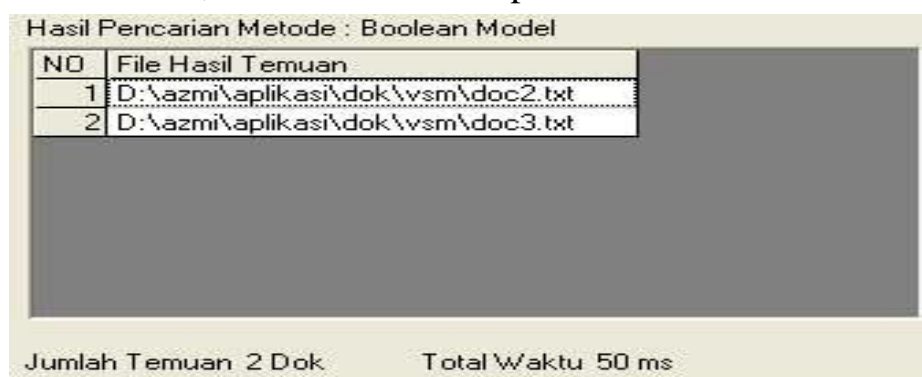

Gambar 6. Hasil Pencarian Boolean Model dengan Operator Or dan And

Gambar 6, terlihat bahwa 2 (dua) dokumen sampel menjadi temuan dan total waktu yang dibutuhkan untuk keseluruhan prosesnya adalah 50 milidetik.

\subsubsection{Pengujian Vector Space Model}

Pada pengujian pencarian dokumen menggunakan VSM, tidak ada pengaruh terhadap operator boolean yang dibahas sebelumnya, sehingga kata kunci yang digunakan cukup satu jenis saja sebagai sampel yaitu "gold silver truck", terlihat pada Gambar 7.

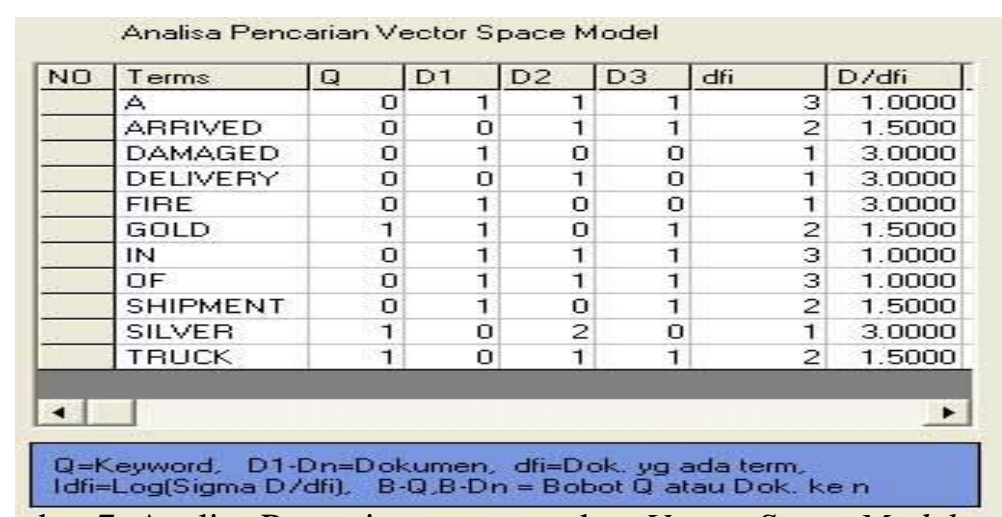

Gambar 7. Analisa Pencarian menggunakan Vector Space Model

Gambar 7, terlihat hasil analisa terhadap pencarian seluruh dokumen dalam folder yang dimaksud sebelumnya. Setelah dilakukan perbandingan terhadap tabel identifikasi kata kunci, maka didapatkan nilai dari setiap kata yang ditemukan dan kaitannya terhadap setiap dokumen. Langkah selanjutnya adalah melakukan Similarity Analysis menggunakan Kesamaan Kosinus yang terlihat dalam Gambar 8.

Gambar 8, terjadi proses puncak untuk menemukan nilai keterkaitan antara dokumendokumen dan kata kunci yang dimasukkan. setelah ditemukan kedekatan dari dokumendokumen tersebut, maka akan disalin ke dalam tabel hasil pencarian dokumen-dokumen yang kedekatannya lebih dari 0,000 seperti dalam Gambar 9 . 


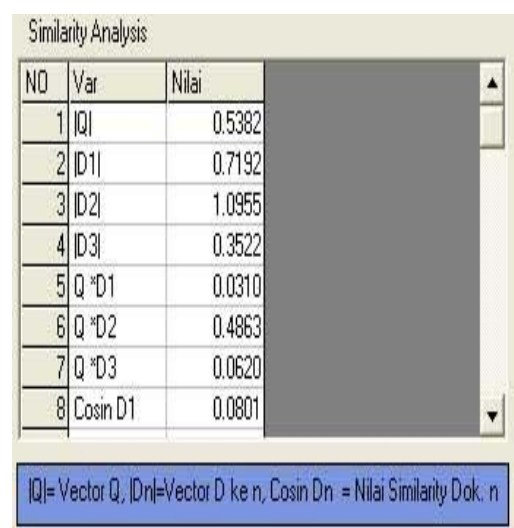

Gambar 8. Similarity Analysis pada Vector Space Model

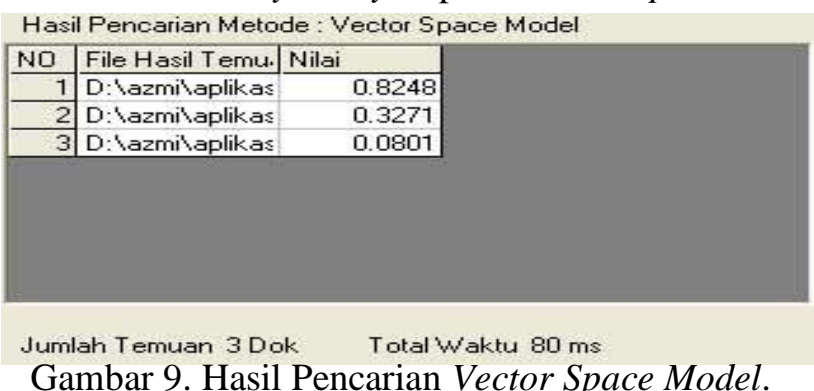

Gambar 9, diatas dapat dilihat bahwa ketiga dokumen memiliki keterkaitan dengan kata kunci, namun posisinya diurutkan dengan nilai kedekatan tertinggi akan lebih dulu ditampilkan dan yang terendah kedekatannya akan ditampilkan dipaling bawah. Total waktu yang dibutuhkan untuk melakukan seluruh proses pencarian ini adalah 80 milidetik.

\subsection{Perbandingan Jumlah Temuan antara Boolean Model dan Vector Space Model}

Berdasarkan pengujian yang dilakukan, didapat tabel hasil perbandingan Pencarian antara Boolean Model dengan Vector Space Model dalam Gambar 10.

\begin{tabular}{|c|c|c|c|c|}
\hline PATH & KEYWORD & JMML SAMPE & JML BOOLEA & NJML VSM \\
\hline D:łazmilaplikasildokłvsm & gold silver truck & 3 & 3 & 3 \\
\hline D:łazmilaplikasi'dokłvsm & gold-silver-truck & 3 & 0 & 3 \\
\hline D: łazmilaplikasiłdokłvsm & gold-silver truck & 3 & 2 & 3 \\
\hline D:łazmilaplikasi'dokłvsm & gold silver-truck & 3 & 2 & 3 \\
\hline
\end{tabular}

Gambar 10. Data Perbandingan Jumlah Temuan

Berdasarkan Gambar 10, dapat dilihat bahwa dari jumlah temuan pencarian dengan VSM akan sama hasilnya dengan Boolean Model jika seluruh kata kuncinya menggunakan spasi atau operator "Or", dan akan lebih banyak hasil temuannya dengan VSM jika salah satu kata kuncinya menggunakan operator "And". Jika dilihat dengan diagram batang perbandingan Jumlah Temuan seperti dalam Gambar 11.

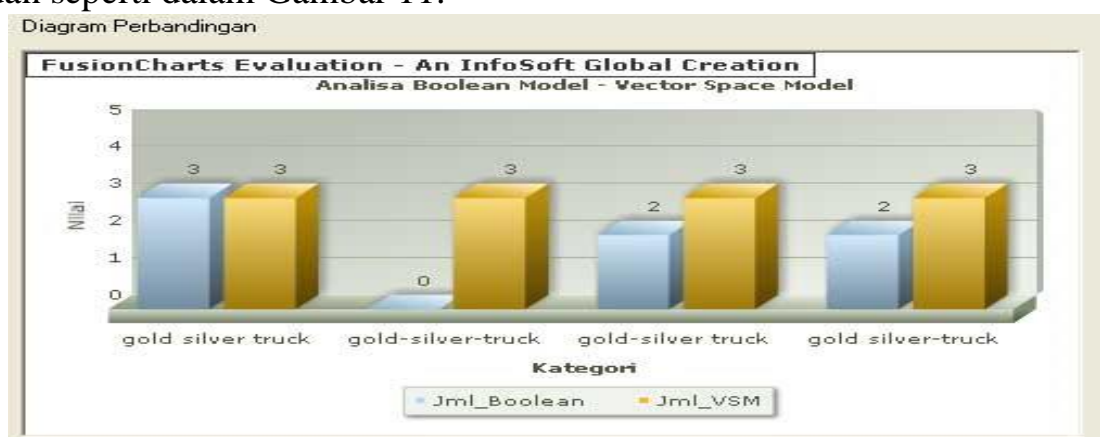

Gambar 11. Diagram Batang Perbandingan Jumlah Temuan 
Perbandingan Jumlah Temuan Secara visual tampak bahwa dari 4 (empat) kata kunci, hanya satu kata kunci yang memiliki hasil temuan sama antara kedua metode, namun tiga kata kunci lainnya menunjukkan hasil temuan yang lebih banyak pada Vector Space Model.

\subsection{Perbandingan Waktu Pencarian antara Boolean Model dan Vector Space Model}

Pada perbandingan waktu pencarian, mengingat kecepatan pencarian harus benar-benar detail maka digunakan satuan waktu = detik bilangan berkoma (desimal). Dari keempat kata kunci dapat dilihat bahwa proses pencarian dengan Boolean Model akan lebih cepat diselesaikan daripada dengan VSM. Hal tersebut terlihat dalam Gambar 12.

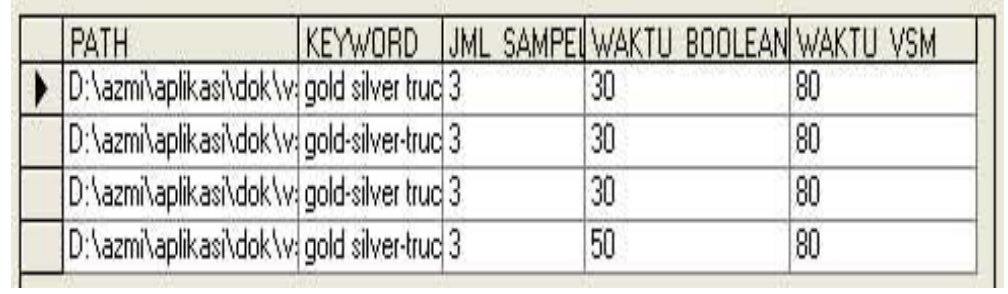

Gambar 12. Data Perbandingan Waktu Pencarian

Jika dilihat dari diagram batang dalam Gambar 13, akan terlihat sekali perbedaan kecepatan penyelesaian pencarian antara Boolean Model dengan VSM. Berikut gambar diagram batang perbandingan waktu pencarian.

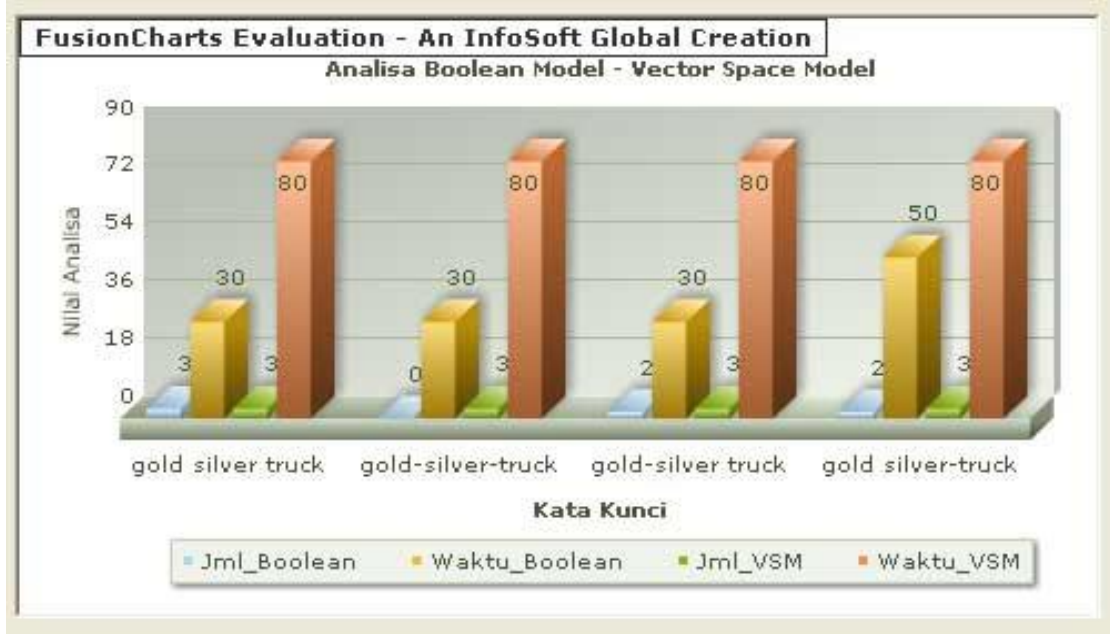

Gambar 13. Diagram Batang Perbandingan Waktu Pencarian

Gambar 13, memperlihatkan bahwa waktu pencarian dengan boolean model menggunakan operator Or, and, gabungan or dan and adalah sebesar 30 detik, sedangkan dengan operator and dan or adalah sebesar 50 detik. Untuk vector space model menggunakan waktu selama 80 detik. Dengan demikian, hasil penelitian ini adalah sama dengan hasil penelitian yang dilakukan oleh [15] yaitu boolean model memerlukan waktu yang lebih sedikit dibandingkan dengan vector space mode dalam pencarian dokumen pada koleksi data.

\section{Kesimpulan}

Kesimpulan dari penelitian yang dihasilkan adalah pada pencarian menggunakan Boolean Model jika operator yang digunakan sebagai kata kunci seluruhnya adalah "Or" maka jumlah temuannya akan sama dengan pencarian menggunakan VSM, dan apabila kata kunci pencarian menggunakan Boolean Model dengan operatornya "And" atau kombinasi operator "And" dan "Or" maka jumlah temuannya akan lebih sedikit daripada VSM. Waktu pencarian menggunakan Boolean Model akan selalu lebih cepat dibandingkan dengan menggunakan VSM meskipun kata kunci menggunakan operator gabungan "And" dan "Or".

Pencarian Dokumen teks menggunakan Boolean Model cocok untuk kata kunci tunggal atau menggunakan operator "Or" secara keseluruhan, jika menginginkan temuan yang banyak. Namun, jika menginginkan temuan yang akurat, maka dapat mengkombinasikan kata kunci 
dengan operator "And" dan "Or" sehingga akan menghasilkan temuan dokumen yang sedikit. Apabila menggunakan VSM dalam pencarian dokumen teks, maka akan menghasilkan jumlah temuan yang maksimal namun dengan waktu pencarian yang lebih lama dibandingkan dengan pencarian dokumen teks menggunakan Boolean Model.

Pencarian dokumen menggunakan Boolean Model dengan operator or, and dan gabungan or dan and didapati bahwa memakan waktu pencarian sebanyak 30 detik, sedangan dengan operator gabungan and dan or memakan waktu sebanyak 50 detik. Sementara untuk vector space model memerlukan waktu sebanyak 80 detik. Berarti selisih yang diberikan adalah boolean model lebih cepat 30 sampai 50 detik untuk proses pencarian dokumen teks.

\section{Daftar Pustaka}

[1] S. Sugiono, H. Herwin, H. Hamdani, and E. Erlin, "Aplikasi Pendeteksi Tingkat Kesamaan Dokumen Teks: Algoritma Rabin Karp Vs. Winnowing," Digit. Zo. J. Teknol. Inf. dan Komun., vol. 9, no. 1, pp. 82-93, 2018, doi: 10.31849/digitalzone.v9i1.1242.

[2] L. W. Pandjaitan, Dasar-dasar Komputasi Cerdas. Yogyakarta: Andi, 2007.

[3] S. A. Zodgekar, Neural Network and Expert System: Concept and Application. Punjagutta: Icfai Books, 2008.

[4] S. . Jain and A. . Gunawardena, Linier Algebra an Interactive Approach. California (USA): Cole-Thomson Learning, 2004.

[5] L. Seimour and L. M. Lars, Schaum's Outlines Teori dan Soal Aljabar Linier Edisi Ketiga. Jakarta: Erlangga, 2006.

[6] D. Susandi and U. Sholahudin, "Pemanfaatan Vector Space Model pada Penerapan Algoritma Nazief Adriani, KNN dan Fungsi Similarity Cosine untuk Pembobotan IDF dan WIDF pada Prototipe Sistem Klasifikasi Teks Bahasa Indonesia," J. ProTekInfo, vol. 3, no. 1, pp. 22-29, 2016.

[7] A. Fauzi and G. Ginabila, "Information Retrieval System Pada File Pencarian Dokumen Tesis Berbasis Text Menggunakan Metode Vector Space Model," J. Pilar Nusa Mandiri, vol. 15, no. 1, pp. 41-46, 2019, doi: 10.33480/pilar.v15i1.61.

[8] B. Sugara, Dody, and Donny, "Sistem Temu Kembali Informasi Pada Gejala Autisme Dengan Metode Vector Space Model," vol. 1, no. 1, pp. 19-25, 2017.

[9] V. Basmalah Wicaksono, R. Saptono, and S. Widya Sihwi, "Analisis Perbandingan Metode Vector Space Model dan Weighted Tree Similarity dengan Cosine Similarity pada kasus Pencarian Informasi Pedoman Pengobatan Dasar di Puskesmas," J. Teknol. Inf. ITSmart, vol. 4, no. 2, p. 73, 2016, doi: 10.20961/its.v4i2.1768.

[10] A. - AMIK BSI Pontianak and A. H. - AMIK BSI Pontianak, "Implementasi Vector Space Model Pada Sistem Pencarian Mesin Karaoke," Evolusi J. Sains dan Manaj., vol. 6, no. 1, pp. 1-6, 2018, doi: 10.31294/evolusi.v6i1.3535.

[11] A. Aziz, R. Saptono, and K. P. Suryajaya, "Implementasi Vector Space Model dalam Pembangkitan Frequently Asked Questions Otomatis dan Solusi yang Relevan untuk Keluhan Pelanggan," Sci. J. Informatics, vol. 2, no. 2, p. 111, 2016, doi: 10.15294/sji.v2i2.5076.

[12] D. Grossman and F. Ophir, Information Retrieval: Algorithms and Heuristics Second Editon. Chicago-USA: Springer, 2004.

[13] F. Lv, H. Zhang, J. G. Lou, S. Wang, D. Zhang, and J. Zhao, "CodeHow: Effective code search based on api understanding and extended boolean model," Proc. - 2015 30th IEEE/ACM Int. Conf. Autom. Softw. Eng. ASE 2015, pp. 260-270, 2016, doi: 10.1109/ASE.2015.42.

[14] T. Georgieva-Trifonova, "Text classification based on enriched vector space model," ACM Int. Conf. Proceeding Ser., vol. Part F1320, pp. 103-110, 2017, doi: $10.1145 / 3134302.3134343$. 
[15] B. Yulianto, W. Budiharto, and I. H. Kartowisastro, "The Performance of Boolean Retrieval and Vector Space Model in Textual Information Retrieval," CommIT (Communication Inf. Technol. J., vol. 11, no. 1, p. 33, 2017, doi: 10.21512/commit.v11i1.2108.

[16] F. Liantoni and A. Yusincha, "Pemodelan UML Pada Sistem Pengajuan Dana Anggaran Untuk Peningkatan Produktivitas Perusahaaan," Digit. Zo. J. Teknol. Inf. dan Komun., vol. 9, no. 2, pp. 94-105, 2018, doi: 10.31849/digitalzone.v9i2.1763.

\section{(c) (i) (2)}

Digital Zone: Jurnal Teknologi Informasi dan Komunikasi is licensed under a Creative Commons Attribution International (CC BY-SA 4.0) 